\title{
Discussion on the Import and Export Trade Structure of China and the United States
}

\author{
Xinyue $\mathrm{Yu}$ \\ Shanghai Deloitte Tax Ltd Jiangsu Branch, Nanjing, China \\ Email: asyu@deloitte.com.cn
}

\begin{abstract}
In order to improve the competitiveness of China's international trade and alleviate the possible trade war with the United States, related data for 2000-2015 years are collected and collocated from the level of trade product structure of China and the United States. Based on the objective reality, and supported by the relevant theories of international trade, the current situation of trade structure of China and the United States is analyzed and summarized. Through the further accurate classification of trade goods, the changes and trends of three types of trade commodities, such as resource intensive, labor intensive and capital intensive types, are studied from various angles of change range of trade commodity structure, trade union degree, commodity coupling degree, and commodity - market coupling degree. This is not only of practical significance to the future trade relations between China and the United States, but also provides some new thinking for the future study of trade between the two countries.
\end{abstract}

Keywords: China and the United States, import trade structure, export trade structure.

\section{Introduction}

Trade is the cornerstone of world economics (Feenstra, 2015). With the development of global economic integration, the scale of trade between countries is expanding and trade competition is becoming more and more intense. In 2013, China became the world's largest trading country that exceeds the United States, but in service trade, it was less than half of the United States. However, the technical content and international competitiveness of the trade goods were promoted to make China a real trade power. Therefore, by comparing with the trade structure of the United States, the current economic situation in China will be further studied and located. As the strongest economy in the world, the trade structure of the United States can be used as a reference for any other country. In order to compare the differences of economic structure between China and the United States, many scholars have done the related research. From the point of view of the product, the dominant comparative advantage is pointed out for the comparison of international competitiveness, and thus the trade structure and the state trade situation of Chins are drawn. Some scholars have studied and compared the industrial structure between the states from the perspective of capital flow.

According to the economic theory, a further classification of trade goods is made based on the HS1992 classification standard, which is divided into three types of products, which are resource intensive, labor intensive and capital intensive. Then, the annual data of the 2000-2015-year trade commodity structure of China and the United States under the HS classification standard, respectively, is used to analyze from the import and export angle. The quantitative analysis of the changes in commodity structure of China and the United States is carried out, and the trade union degree and Laurence index are used to compare and analyze the coupling degree and interdependence of China and the United States and the extent of their interdependence. From the perspective of trade commodity structure, it is of great significance to study the trade development between China and the United States.

\section{Present Situation of the Product Trade Structure Between China and the United States}




\subsection{The Current Situation of the Development of Foreign Trade in China and the United States}

Since twenty-first Century, with the acceleration of the process of economic globalization, the trade economy of various countries has also begun to flourish, and trade and transnational production has brought great benefits to countries (Ramondo and Rodríguez-Clare, 2013). The United States and China, as the world's first and second largest economies, have witnessed rapid development in international trade. China is the world's largest exporter and the world's second largest importer, and the United States is the world's largest importer. There was report pointed out that China would be the largest economy in the United States by the end of 2024 (Prial, 2014). In addition, some scholars compared the influence of the Asia Pacific region economy globalization dominant by the United States and China on the global agricultural trade pattern (Heerman, Arita, and Gopinath, 2015). As a result, the two countries' economies will have a significant impact on each of them (Morrison, 2015), and also play an important role in the development of world trade.

There are many factors that influence the development of China's transnational trade, including culture, geography and so on (Wan, Gao, and School, 2014). Before 2001, China's import and export trade had always been in its infancy. Until the entry of World Trade Organization (WTO) in 2001, endogeneity is corrected by using specific quotas of products (Bloom, Draca, and Van Reenen, 2016), and China's foreign trade began to develop rapidly. In terms of export trade, the export trade of China and the United States had developed slowly before 2001. Since 2001, the total export trade of China and the United States began to increase rapidly except for the decline in the export trade affected by the financial crisis in 2008, but the growth rate of China's export trade was far more than that of the United States. By 2007, China's export trade exceeded that of the United States, and by 2009, China became the largest exporter in the world. The export trade volume increased from 149 billion US dollars in 1995 to 2.34 trillion US dollars in 2014, and the export trade volume was nearly 20 times in 20 years. In terms of import trade, the United States, as the world's largest importer, its import trade volume is always more than that of China. However, it is worth noting that China's import trade has also been growing rapidly since 2001, and it has become the second largest commodity importer in the world. The gap of import trade between China and the United States is gradually narrowing. In the field of foreign trade balance, China's foreign trade has always maintained a "surplus" state of trade in the past 19952014 years, the export trade is greater than the import trade, and the overall trend of trade balance is increasing in addition to the impact of financial crisis. Contrary to China, the import trade of the United States is much larger than the export trade that is always in the state of "deficit", and the trade balance is also showing a growing trend.

\subsection{The Structure of Foreign Trade Between China and the United States}

Comparison of export products trade structure between China and the United States: from the point of view of the product, the United States as the world's first power, its economic development started earlier, and has various kinds of capital and high quality of technical level. And its industrial structure has already stepped into a relatively stable stage. Therefore, the development of export trade structure of the United States is also relatively mature, and the export products structure tends to a relatively stable stage. In the past 1995-2014 years, the top 20 commodities in the United States' export trade were changed in the order of export ranking, but the overall change was not significant. It was always based on capital intensive products, such as vehicles, auto parts, measurement, inspection, analysis and control instruments and devices, as well as automatic data processing devices, telecommunications equipment, pharmaceuticals, medical equipment and other technology-intensive products, accounting for more than $48 \%$ of the total annual exports of the United States. In contrast, China's export trade structure has changed considerably over the years. In 1995, China's export trade structure was dominated by labor-intensive furniture, textiles, clothing and footwear. Among them, textile and garment exports accounted for most of the proportion, and its exports accounted for $22.57 \%$ of China's total exports. After ten years of development, by 2004, China's export trade structure has changed significantly. Although in the composition of top 20 export commodities, labor-intensive textile and clothing products, footwear, etc. still occupy a large proportion, the export of automatic data processing equipment, telecommunications equipment, office equipment spare parts, semiconductors and so on has 
begun to replace some traditional textile clothing and become the main export goods of China. By 2014, capital-intensive manufacturing exports accounted for most of China's exports. Although the export of labor-intensive textile and clothing still occupies a considerable proportion, the overall export trade structure of China has changed from the original single labor-intensive product export to the capitalintensive product export.

Comparison of import trade structure between China and the United States: in terms of import product trade structure, the changes of the former 20 kinds of imported products in the United States have little difference between the sample. In contrast, the nature of some imported products in China has changed greatly. In the past 1995-2014 years, the import of crude oil and manned vehicles in the United States remained the most important in the import of various products, and the proportion of the total imports of the United States reached $16.99 \%$ in 2014. Other major imports are mainly capital technology intensive, such as telecommunications equipment, auto parts, automatic data processing equipment, etc., and labor-intensive products, such as industrial products and furniture, textile and clothing and footwear. In the past 1995-2014 years, China's import trade structure is still mainly dominant by the import of automatic data processing equipment, semiconductors, telecommunications equipment, auto parts and other high capital and technology intensive industrial products. But it is worth noting that in 1995, in China's import trade structure, textile yarn, leather and textile as well as leather machinery and parts still need a large number of imports to meet the production and development of textile and clothing industries. After joining WTO, by 2004, the oil, iron ore and its concentrate, oil products, copper and other energy resource products and other chemicals are imported in a large amount to meet the development of the growing processing and manufacturing industry. By 2014. China's import trade structure has tended to be dominated by imports of resource-intensive, technology-intensive industrial products and energy-resource products. The import trade structure of China and the United States accounts for most of the import of capital technology intensive industrial products, such as telecommunications equipment, semiconductors, auto parts, automatic data processing equipment and so on. But the difference is that the United States, because of the high cost of domestic labor, needs to rely heavily on imports in labor-intensive products such as textile, clothing, footwear and furniture. As a large population country, China is relatively poor in mineral resources. In order to meet the national strategic demand, the import demand for energy resources such as crude oil, iron ore and its concentrate, natural gas and so on is expanding.

\section{Quantitative Analysis of the Changes in Trade Commodity Structure Between China and the United States}

\subsection{Analysis of Coupling Degree and Interdependence of Trade Commodity Structure of China and the United States}

The degree of trade combination proposed by the famous Japanese economist Kojima is the most commonly used indicator to measure the degree of trade tightness between two countries. Many scholars at home and abroad have used this index to analyze and study the trade complementarity and feasibility of the related products of different countries in the study of international trade relations. The degree of trade combination includes narrow trade combination and broad trade combination. The difference between the two is that the former only calculates the degree of commodity coupling of a trade commodity between the two countries, that is, the similarity between the structure of the $\mathrm{i}$ product exported by the A country to the B country and the structure of the i product imported from the whole world, while the latter introduces the relationship between the products and the market, that is, to measure the product - market coupling degree of a certain trade product of the two countries. In other words, on the basis of considering the degree of coupling of the product structure, further consideration is made from the export product structure of the exporting country and the market demand level of the importing country, reflecting the product - market combination degree.

Trade combination: the product coupling degree and product - market coupling degree of three kinds of trade products in China and the United States, which are resource intensive, labor intensive and capital intensive trade products are analyzed and judged by combining the narrow trade combination degree, the generalized trade combination degree, the export trade combination degree and the import 
trade combination degree.

In the narrow sense, the method for calculating the export trade combination degree is shown in Formula 1:

$$
N I C D_{X C A, i}^{t}=\left(\mathrm{X}_{C A, i}^{t} / \mathrm{X}_{C W}^{t}\right)\left(\mathrm{M}_{A C, i}^{t} / \mathrm{M}_{A W}^{t}\right)
$$

$N I C D_{X C A, i}^{t}$ indicates the export trade combination degree in narrow sense of China to i product of the United States during the $\mathrm{t}$ period; $\mathrm{X}_{C A, i}^{t}$ means the export volume of i product of China to the United States during the $\mathrm{t}$ period; $\mathrm{X}_{C W}^{t}$ denotes the total exports of China to all commodities during the $\mathrm{t}$ period; $\mathrm{M}_{A C, i}^{t}$ suggests the import of $\mathrm{i}$ goods in the United States from China during the t period; and $\mathrm{M}_{A W}^{t}$ refers to the total imports of goods of the United States from the world during the $\mathrm{t}$ period.

The method for calculating the export trade combination degree in generalized sense is shown in Formula 2:

$$
G I C D_{X C A, i}^{t}=\left(\mathrm{X}_{C A, i}^{t} / \mathrm{X}_{C W, i}^{t}\right)\left(\mathrm{M}_{A C, i}^{t} / \mathrm{M}_{A W, i}^{t}\right)
$$

$G I C D_{X C A, i}^{t}$ represents China's generalized export trade combination degree of China to i product in the United States during the t period; $\mathrm{X}_{C A, i}^{t}$ refers to the export volume of i product of China to the United States during the $\mathrm{t}$ period; $\mathrm{X}_{C W, i}^{t}$ suggests the export volume of i product of China to the world during the t period; $\mathrm{M}_{A C, i}^{t}$ means the import of i product of the United States from China during the $\mathrm{t}$ period; and $\mathrm{M}_{A W, i}^{t}$ indicates the import of i product of the United States from the world during the $\mathrm{t}$ period.

The method for calculating the import trade combination degree in narrow sense is shown in Formula 3:

$$
N I C D_{M C A, i}^{t}=\left(M_{C A, i}^{t} / M_{C W}^{t}\right)\left(X_{A C, i}^{t} / X_{A W}^{t}\right)
$$

$N I C D_{M C A, i}^{t}$ indicates the import trade combination degree of i product of China from the United States during the t period; $M_{C A, i}^{t}$ suggests the import volume of i product of China from the United States during the t period; $M_{C W}^{t}$ means the total import volume of product of China from the whole world during the t period; $X_{A C, i}^{t}$ is the export volume of i product of the United States to China during the $\mathrm{t}$ period; and $X_{A W}^{t}$ represents the total export volume of the United States to all the products of the world during the t period.

The method for calculating the import trade combination degree in generalized sense is shown in Formula 4:

$$
G I C D_{M C A, i}^{t}=\left(M_{C A, i}^{t} / M_{C W, i}^{t}\right)\left(X_{A C, i}^{t} / X_{A W, i}^{t}\right)
$$

$G I C D_{M C A, i}^{t}$ is the import trade combination degree in generalized sense of i product of China from the United States during the t period; $M_{C A, i}^{t}$ denotes the volume of product of China importing from the United States during the t period; $M_{C W, i}^{t}$ suggests the volume of i product of China importing from the world during the t period; $X_{A C, i}^{t}$ indicates the volume of i product of the United States exporting from China during the $\mathrm{t}$ period; $X_{A W, i}^{t}$ represents the volume of i product of the United States exporting from the world during the $\mathrm{t}$ period.

\subsection{The Change Range of Trade Product Structure in China and the United States}

The Lawrence index: in 1996, Sapir proposed an index that can be used to measure the range of changes in trade structure between two countries - the Laurence index, which is calculated as Formula 5.

$$
L=(1 / 2) \sum\left|S_{i, t}-S_{i, t-1}\right|
$$

In Formula 5, L is the Lawrence index, $S_{i, t}=\mathrm{X}_{\mathrm{i}, \mathrm{t}} / \sum \mathrm{X}_{\mathrm{i}, \mathrm{t}}$, which indicates the proportion of product i's exports to the country's total exports during the t period. The Laurence index $\mathrm{L}$ is valued in the range 
of 0 to 1 , that is, when the value of $\mathrm{L}$ is closer to 0 , the less the trade product structure changes between the two countries is; conversely, when the value of $\mathrm{L}$ is closer to 1 , the greater the change of trade product structure between the two countries is.

\section{$4 \quad$ Results and Discussion}

\subsection{Export Trade Combination Degree of Various Products of China and the United States in Narrow Sense}

The data collected by the United Nations Comtrade database is used to calculate the narrow export trade combination of all kinds of products between China and the United States in 2000-2015 years according to Formula 1, as shown in Figure 1.

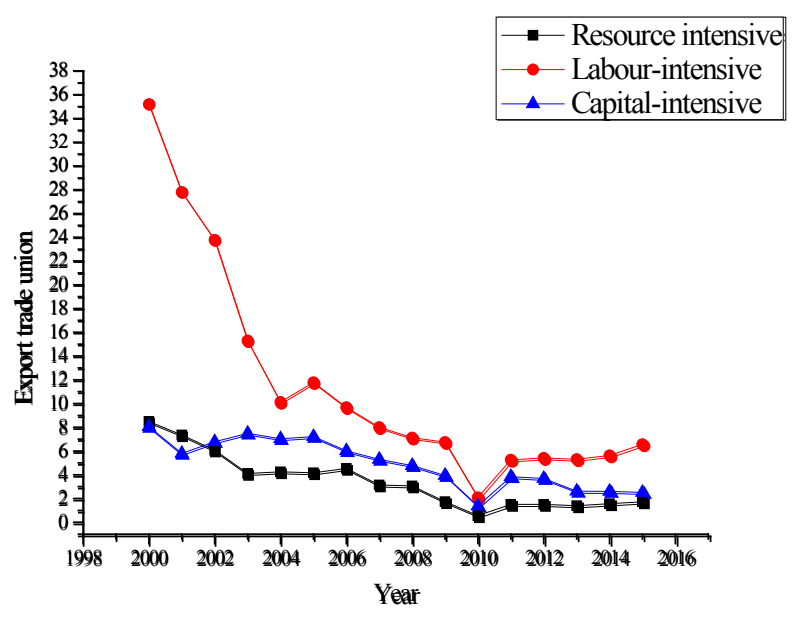

Figure 1. Narrow export trade combination between China and the United States from the year of 2000 to 2015

According to Figure 1, the narrow sense export trade combination of three kinds of products during the 2000-2015 years is greater than 1 except for the narrow export trade combination of resourceintensive products less than 1 in 2010. The change of the narrow export trade combination of resourceintensive products and capital labor-intensive products is not obvious and relatively smooth, but the narrow export trade combination of labor-intensive products fluctuates relatively, especially during the 2000-2004 years. Then, it is relatively smooth, and only has a small fluctuation once again in 2010.

According to Formula 2, the data collected by the United Nations Comtrade database is used to calculate the generalized export trade combination of the various products of the United States and China for 2000-2015 years. The results show that the generalized export trade combination of the three types of products are both obvious in 2000-2010 years, and then relatively smooth. Among them, the generalized export trade combination of resource-intensive products and labor-intensive products is more than 1. The fluctuation of the generalized export trade combination of capital-intensive products is the most obvious, and it is less than 1 in 2010 .

\subsection{Import Trade Combination of All Kinds of Products Between China and the United States in Narrow Sense}

In accordance with Formula 3, the data collected by the United Nations Comtrade database is used to calculate the import trade combination between China and the United States for 2000-2015 years in narrow sense, as shown in Figure 2.

According to Figure 2, the import trade combination of resource-intensive products in narrow sense is not very high during the 2000-2015 years. After 2008, it is even lower than 1 and again more than 1 in 2015 , and the overall change is relatively stable; the narrow sense import trade combination of laborintensive products is always larger than 1 and relatively high. And before 2001, the fluctuation was very 
obvious, then the change was relatively stable, only a small fluctuation appeared in 2010; the narrow sense import trade combination of capital-intensive products was not high, and the change was relatively stable and less than 1 in 2010-2012 years.

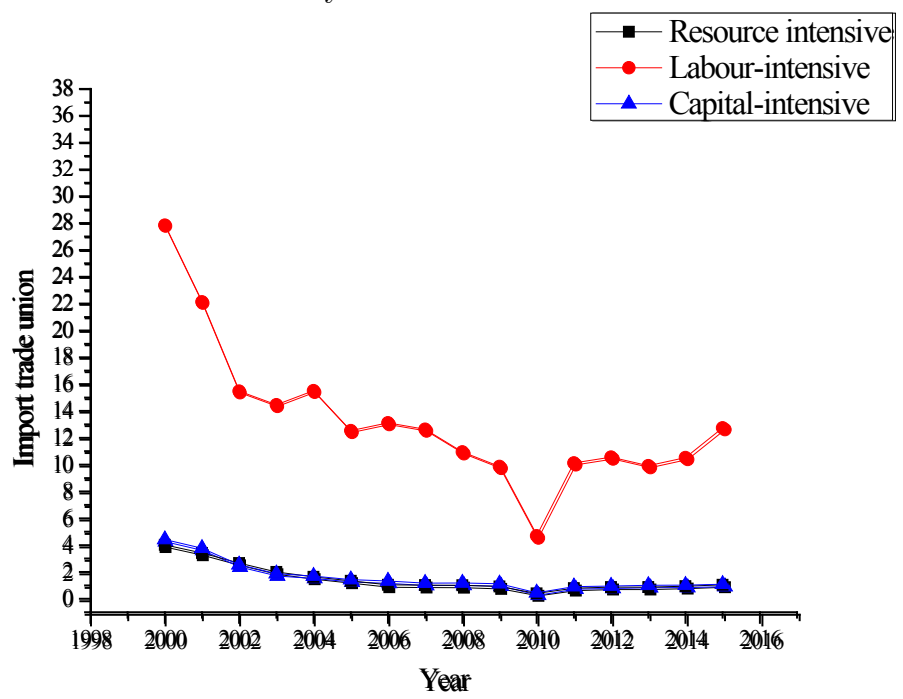

Figure 2. Narrow import trade combination of Chinese and American products from the year of 2000 to 2015

\subsection{The Change Range of the Export Product Structure of China and the United States}

Based on Formula 5, the data collected by the United Nations Comtrade database is used to calculate the Lawrence Index of all kinds of products exported by China to the United States for 2000-2015 years, as shown in Figure 3.

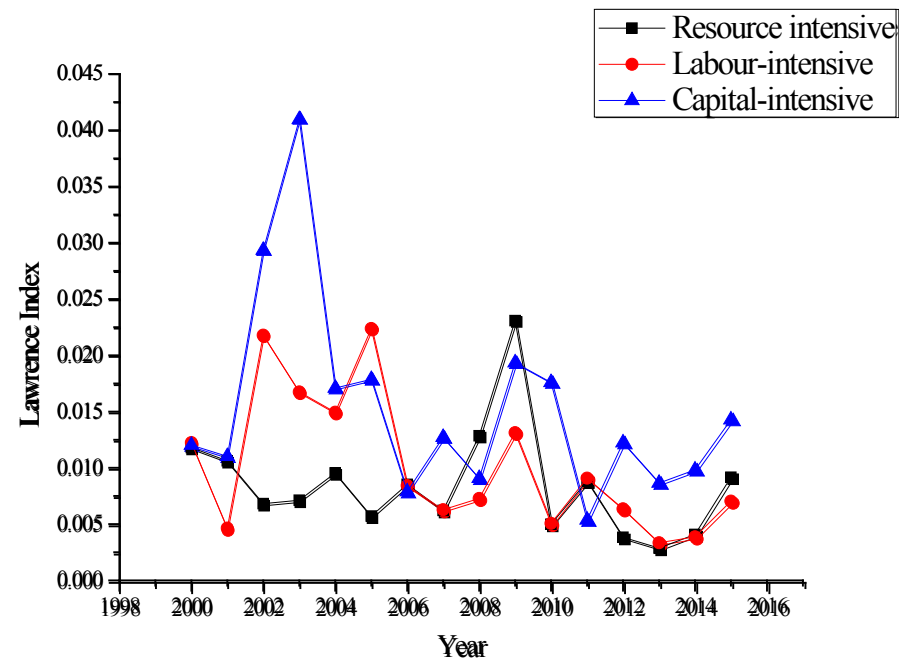

Figure 3. Laurence index of China's exports to the United States from the year of 2000 to 2015

Figure 3 shows that there are obvious fluctuations in the 2008 and 2009; the Laurence index of China's labor-intensive exports to the United States is in a relatively fluctuated situation, especially obvious in the period of 2001. It indicates that the structure change of China's labor-intensive products exported to the United States is more obvious at this stage. The Laurence index of China's capitalintensive exports to the United States is sharply fluctuated in 2001, and is always fluctuating in a smaller range. 


\subsection{The Change Range of China's Import of Product Structure from the United States}

According to Formula 5, the data collected by the United Nations Comtrade database is used to calculate the Lawrence Index of all kinds of products imported by China from the United States for 2000-2015 years, as shown in Figure 4.

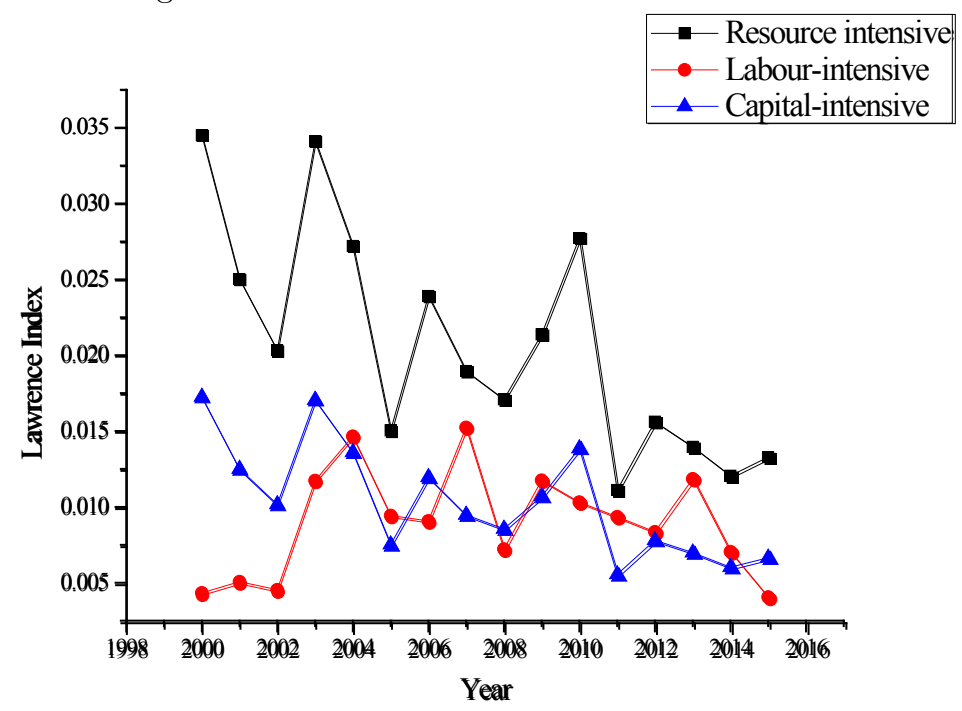

Figure 4. Laurence index of products imported from the United States from the year of 2000 to 2015

Figure 4 shows that the Laurence index of the three products imported by China from the United States has always been in a state of relative fluctuation.

\section{Conclusion}

The quantitative analysis of the changes of the trade product structure of China and the United States shows that both the narrow sense of import and export trade combination and the general import and export trade combination, present such a rule and trend: the fluctuation is intense, and the change is obvious before 2001, and it has been stable since the beginning of 2004. Only during 2008-2010 years, there is a small fluctuation, but the change is not obvious. In addition, the United States has always been the advanced export market for China's three types of resource-intensive, labor-intensive and capital-intensive products, but it is not its advanced import market, and even the secondary import market appears in resource-intensive and capital-intensive products. Moreover, the Laurence index is less than 1 and is closer to 0, especially the Laurence index of China imported from the United States, which is close to 0, indicating that the trade structures of China and the United States are relatively stable to some extent.

\section{References}

1. Feenstra R C. (2015). Advanced International Trade: Theory and Evidence Second Edition[J]. Economics Books, $66(2), 541-544$.

2. Ramondo N\&Rodríguez-Clare A. (2013). Trade, Multinational Production, and the Gains from Openness[J]. Journal of Political Economy, 121(2), 273-322.

3. Prial D. (2014). China Will Have World's Largest Economy By 2024: Report[J].

4. Heerman K E R\&Arita S\&Gopinath M. (2015). Asia-Pacific Integration with China versus the United States: Examining Trade Patterns under Heterogeneous Agricultural Sectors[J]. American Journal of Agricultural Economics, 97(5). 
5. Morrison W M. (2015). China's Economic Rise: History, Trends, Challenges, and Implications for the United States[J]. Congressional Research Service Reports, 23.

6. Wan L L\&Gao X\&School E. (2014). The Influence of Cultural,Geographical and Institutional Distance on China's Import and Export Trade:An Empirical Test of the Trade Data with 32 Countries or Regions[J]. International Economics \& Trade Research.

7. Bloom N\&Draca M\&Van Reenen J. (2016). Trade Induced Technical Change? The Impact of Chinese Imports on Innovation, IT and Productivity[J]. Cepr Discussion Papers, 83(1), 1-13 